\title{
Some Proposed Guidelines for Advocacy in the Classroom
}

\author{
Ellis M. West, University of Richmond
}

In this article, I do not attempt to make the case for advocacy in the classroom, by which I mean any attempt by a teacher to convince students to believe some proposition or take some action. Rather, I take it for granted that college teachers do and should engage in classroom advocacy. For me, therefore, the crucial questions are what, how much, and in what way teachers should advocate-not whether they should do so. I am concerned, in other words, with what distinguishes legitimate from illegitimate advocacy. This essay proposes a partial answer to this question. It is partial because the guidelines for classroom advocacy that I propose pertain only to the manner of advocacy, and not to its content or extent, and are justified mostly on educational, rather than practical, legal, or ethical, grounds.

My proposed guidelines are based on four assumptions about the nature and purpose of a liberal arts education. The first is that its primary purpose is to assist students and faculty in discovering the truth, including ways of doing so. In other words, the primary activity at a liberal arts institution should be "intellectual inquiry." The second is that, in seeking the truth, students and faculty can and should think for themselves, as opposed to unquestioningly accepting the views of others. My third assumption is that students and faculty should be rational, in the minimal sense that they should not accept a belief without first comparing it to competing beliefs and then being able to give rea-

Ellis West is professor of political science at the University of Richmond, where he teaches political theory and constitutional law. In 1991, he received a Distinguished Educator Award. Having published numerous articles on the religion clauses of the First Amendment, he is now finishing a book on the original meaning of the tree exercise clause. sons for accepting it. Finally, I assume that, in their search for the truth, students and faculty can and should be sufficiently disinterested and open-minded to allow learning to occur.

I now turn to the key question, "How should advocacy in the classroom be done?" In general, my answer is that it should be done in a way that is consistent with, and certainly does not undercut, the nature and aims of a liberal arts education stated above. Teachers should be able to defend most of their classroom advocacy on the grounds that it helps their students to learn the truth for themselves. Even the vigorous advocacy of a controversial view-Bach was the greatest composer who ever lived; gun control laws are needed; abortion should be outlawed-can teach students much about truth and how it can be known, if it is done in the right way.

Although some might argue that the "right way" of advocating is one that conforms to some kind of ideal, I require only that advocacy generally adhere to four basic principles. One, as much as possible given the material to be covered in a course, advocacy should be explicit and identified as such by the teacher. This makes it less likely than would otherwise be the case that a position will be advocated by teachers and accepted by their students without either of them thinking about its validity. "Open advocacy," Ernst Benjamin argued, "may better safeguard a student's right to form an independent judgment than the implicit bias inherent in the presumption that the faculty member's presentation is simply factual. Even 'balanced' presentations depend on a particular formulation of the dispute and the alternatives" $(1996,307){ }^{1}$

Two, advocacy should be reasoned and informed, in the sense that whatever is advocated should be supported, as well as defended from arguments against it, with reasons that the teacher honestly believes to be valid. At a minimum, teachers should never use dishonesty or deception to get their students to accept a position. What is important, however, is not so much that the teachers' reasons actually be valid or even the right kind of reasons, but simply that reasons be given in good faith so that the students are "invited" to consider and evaluate them. Peter Markie gave a helpful explanation of this requirement:

\footnotetext{
Students are capable of determining what they will believe, and they have an intellectual obligation to strive to attain true beliefs and avoid false ones by assessing the evidence for and against each claim that comes before them. To respect their autonomy and rationality, we must give them reasons for what we ask them to believe and we must ensure that they have the ability to assess those reasons for themselves $(1996,297)$.
}

Three, teachers should allow free and open discussion of the positions they advocate. More specifically, they should allow students to challenge their views. Because free and open discussion is especially important as a way of getting students to think for themselves, teachers should work to avoid intimidation, perhaps by ending every explicit advocacy with something like, "Now, what do you think of that?" For this third requirement to be met, teachers should also, when possible, grade exams and papers "blindly" and should assure their students that they are doing so. Finally, students' grades should not be influenced by whether the students agree with what their professors advocate, although they should be expected to understand it. ${ }^{2}$ I think it is wrong for a teacher to have the kind of attitude that is reflected in the following statement: "I let my students know where I'm coming from, and 
also that they're free to write papers which disagree with the position I've taken in class. But those papers had better be very, very good because I'll read them with a more critical eye than the ones I agree with." 3

Four, advocacy should be civil and reflect respect for the students. Derogatory or abusive remarks about individual students or groups of students should have no place in the classroom.

Each contribution to a discussion should be listened to carefully and taken seriously, although not necessarily accepted or left unchallenged.

Of these proposed guidelines for advocacy, perhaps the one that is most likely to be questioned is the third-teachers should allow for free and open criticism of what they advocate. This might trouble some teachers because it requires that they allow their students to express views that they detest. It could be argued, moreover, that if departments, schools, or universities prohibit teachers from advocating certain positions, on the grounds that they are illegal, immoral, or irrational, students should also be prohibited from advocating those positions. Although this argument has validity, I am not prepared to go beyond this and say that, on their own, teachers have the right to proscribe or penalize the expression of views that have not been proscribed by the larger institution of which both teachers and students are a part. To the extent that teachers have a responsibility in their classrooms to encourage good and discourage evil, I would argue that all that they are required to do to fulfill that responsibility is to state their views as clearly and persuasively as they can. Surely, the suppression of beliefs thought to be wrong or irrational has no place in a college classroom, except in those cases where the institution as a whole, after careful deliberation, has made a judgment to that effect.

Beyond these four limitations, I would not go. For example, I would not require, as some do (Brand 1996; Ackerman 1996), that advocacy be "fair" and "balanced."

Such a requirement is impractical and comes close to meaning that teachers can advocate only if their advocacy is ineffective. Whether this is a fair criticism depends, of course, on exactly what is meant by fairness or balance, but if what is meant is equal time for all positions on an issue, ${ }^{4}$ the presentation of the strongest possible case for each of them (Ackerman 1996), or the elimination of all hierarchies, authorities, and power relations within the classroom (Glennon 1995), then I would argue that such a requirement is, for all practical purposes, inconsistent with a teacher's ability to advocate. To limit advocacy to situations where all participants and all points of view are equal in power is to prohibit all advocacy, for such a situation is simply not possible, and it is naïve to assume otherwise. If, however, fairness or balance is defined less strictly (as, for instance, requiring only the mentioning of some opposing positions/arguments and their sources), then perhaps both advocacy and fairness can and should be combined in the classroom.

I also have a problem with an- other widely proposed limitation on the manner of advocacy that teachers may use, namely, that teachers should not engage in "indoctrination" or "proselytizing." As Pinsker (1995) notes, these terms are often not defined, especially by those who try to defend advocacy by distinguishing it from, say, indoctrination, but who do not really want to limit it in any meaningful way. On the other hand "indoctrination" and "proselytizing" are sometimes so broadly defined that their prohibition would preclude all advocacy, that is, disallow all attempts to convince students of the correctness of a particular belief or action. ${ }^{5}$ Moreover, attempts to distinguish between advocacy and proselytizing are usually unsuccessful. An example comes from Myles Brand: "Proselytizing ... has an ulterior motive not present in advocacy ... to persuade, cajole, and in some fashion coerce the listener ... to adopt personally the position advocated. Proselytizing ... refers to the mode of presentation, the intentions and motives of the teacher.... To proselytize is to attempt to convert the listener to one's position" (1996, 9-10). Such an explanation of proselytizing is confusing because it is not clear whether it refers to all attempts to convert the student to the teacher's position, including attempts to persuade, or refers only to attempts to convert through coercion. Not surprisingly, Brand goes on to admit that "sometimes it can be quite difficult to decide whether the speaker is proselytizing or advocating a position. ... It is better, then, to think of a continuum between advocacy and proselytizing" (10).

Even if what persons who condemn proselytizing and indoctrination have in mind is coercive advocacy, which often appears to be the case (Benjamin 1996; Strossen 1996), I am not convinced that a rule against coercive advocacy is meaningful and, thus, helpful. Although in principle I am certainly opposed to teachers' coercing their students into believing or doing anything, the problem is that it is very difficult, if not impossible, to say what constitutes coercion and to know when it occurs. Not surpris- 
ingly, it has bedeviled both scholars (Pennock and Chapman 1972; Wertheimer 1988) and judges." Whether there is coercion in the classroom depends to a large extent on the strength of the students' psyches, which makes it, therefore, a very subjective question. On the other hand, it is also obvious that certain ways of trying to influence students (for example, those that consist mostly of appeals to emotions) are very likely to short-circuit the critical or reasoning capacities of the students and thus to be coercive in nature.

Therefore, just as the Supreme Court in Miranda v. Arizona (1966) decided that the most effective way of preventing the police from using coercion in obtaining confessions was to require them to meet certain objective requirements or conditions (that is, to inform defendants of their rights), I would argue that the problem of coercion in the classroom can be eliminated for the most part if teachers adhere to the four specific guidelines outlined in this paper. If, as much as possible, advocacy in the classroom is explicit, consists primarily of good faith reasons, can be discussed and challenged by the students, and is expressed in a civil and respectful way, that, in my opinion, would be enough to protect the freedom of the students and the integrity of their liberal arts education and, consequently, also enough to legitimate the advocacy itself.

\section{Notes}

1. In agreement is the American Civil Liberties Union Policy Guide, which states, "If such judgment [the teacher's] is clearly stated, students are better able to appraise it and to differ from it on the basis of other materials and views placed at their disposat than they would be if a teacher were to attempt to conceal bias by a claim to 'objective' scholarship" (quoted in Strossen 1996, 72).

2. "Student performance should be evaluated solely on an academic basis, not on opinions or conduct in matters unrelated to academic standards" (American Association of University Professors 1995, 228).
3. Ann Shaver, a women's studies professor who attended the 1995 Conference on the Role of Advocacy in the Classroom (quoted in Pinsker 1995).

4. This has been called the "zoo theory" and "Noah theory" of classroom presentation (Voll 1996, 173).

5. For example, although Penny Gold appears to defend advocacy, she distinguishes it from "proselytizing," by which she means "trying to convince others of it [a position]." She goes on to say, "I do not see it as my task to convince people to adopt my position. ... I am not out to proselytize. If a 'conver- sion' occurs, it will be because of the longterm impact of thinking about and responding to the variety of positions expressed in the class..., not because I have actively gone out to convince someone" $(1996,261)$. Obviously, such a position would preclude the kind of advocacy I am implicitly defending in this essay.

6. For example, see the debate between Supreme Court Justices Kennedy and Scalia in Lee v. Weisman (1992), over whether a public prayer at a high school graduation exercise, at which attendance is not required, entails coercion of religious worship.

\section{References}

Ackerman, Felicia. 1996. "Be Reasonable and Do It My Way: Advocacy in the College Classroom." In Advocacy in the Classroom: Problems and Possibilities, ed. Patricia M. Spacks. New York: St. Martin's Press.

American Association of University Professors. 1995. "Joint Statement on Rights and Freedoms of Students." In AAUP Policy Documents and Reports. Washington, DC: American Association of University Professors.

Benjamin, Ernst. 1996. "Some Implications of the Faculty's Obligation to Encourage Student Academic Freedom for Faculty Advocacy in the Classroom." In Advocacy in the Classroom: Problems and Possibilities, ed. Patricia M. Spacks. New York: St. Martin's Press.

Brand, Myles. 1996. "The Professional Obli- gations of Classroom Teachers." In Advocacy in the Classroom: Problems and Possibilities, ed. Patricia M Spacks. New York: St. Martin's Press.

Glennon, Fred. 1995. "The Leaming Covenant: Promoting Freedom and Responsibility in the Religious Studies Classroom." The Council of Societies for the Study of Religion Bulletin 24(April): 32-37.

Gold, Penny. 1996. "A Teacher Is Either a Witness or a Stranger." In Advocacy in the Classroom: Problems and Possibilities, ed. Patricia M Spacks. New York: St. Martin's Press.

Lee v. Weisman. 1992. 505 U.S. 577.

Miranda v. Arizona. 1966. 384 U.S. 436.

Markie, Peter. 1996. "The Limits of Appropriate Advocacy." In Advocacy in the Classroom: Problems and Possibilities, ed.
Patricia M. Spacks. New York: St. Martin's Press.

Pennock, J.R., and J.W. Chapman, eds. 1972. Coercion. Chicago: Aldine Press.

Pinsker, Sanford. 1995. "Those Who Can, Do. Those Who Can't, Advocate." Wall Street Joumal, June 29, A16.

Strossen, Nadine. 1996. "First Amendment and Civil Liberties Traditions of Academic Freedom." In Advocacy in the Classroom: Problems and Possibilities, ed. Patricia M. Spacks. New York: St. Martin's Press.

Voll, John O. 1966. "Advocacy and Explanation: The Problems of Explaining Adversaries." In Advocacy in the Classroom: Problems and Possibilities, ed. Patricia M. Spacks. New York: St. Martin's Press.

Werthejmer, Alan. 1988. Coercion. Princeton: Princeton University Press. 